\title{
The science behind Bayley $v$ The Queen (2016)
}

\author{
Alena Skalon* and Jennifer L. Beaudry \\ Department of Psychological Sciences; School of Health Sciences; Faculty of Health, Arts and \\ Design; Swinburne University of Technology, Melbourne, Australia
}

\begin{abstract}
Eyewitness identification was the principal evidence in DPP $v$ Bayley (2015), wherein Adrian Bayley was convicted of raping and assaulting a woman in 2000. Twelve years after the attack, the victim identified Bayley from a photograph on Facebook and later in a formal police identification procedure. At the time of the initial Facebook identification, the victim knew about Bayley's involvement in Gillian Meagher's case. Bayley successfully appealed his conviction in 2016. The court of appeal held that the identification evidence had multiple weaknesses and should not have been permitted at the initial trial. In their decision, the court relied on legal precedents to support their judgement. This article reviews the empirical evidence regarding each of the issues raised by the court and how the stressfulness of an event can influence the reliability of an identification, and speculates about why the jury rendered a guilty verdict based on weak identification evidence.
\end{abstract}

Keywords: eyewitness identification; identification procedure; photoboard identification; identification evidence; Facebook identification; Bayley; eyewitness evidence

Identification evidence often plays an important role in criminal trials, and DPP v Bayley (2015; conviction trial 1) is an example of a defendant being convicted based almost entirely on an identification made by the victim. Alarmingly, the jury convicted Adrian Bayley despite multiple weaknesses in the identification evidence in this case. The court of appeal ruled that the evidence should not have been permitted in the initial trial due to a number of factors. This article reviews the empirical evidence in relation to each of the issues raised by the court. Specifically, it discusses how delay can affect identification accuracy, potential problems with an identification from a single photograph, the influence of expectations on people's decisions and how a change in the perpetrator's appearance between the crime and the identification can affect identification accuracy. The way in which prior exposure to the suspect's photograph can influence subsequent identification attempts (referred to by the courts as the 'displacement effect') is also discussed, along with the distinction between evidence of identification and evidence of similarity. Two additional factors not mentioned in the appeal decision are also raised: the impact of stress on identification reliability and potential explanations for why the jury convicted Adrian Bayley at the initial trial.

This case brings to light some of the most frequently discussed issues associated with eyewitness identification evidence. Who should determine the reliability of this evidence? When should it be deemed inadmissible? Can juries appropriately evaluate the quality of identification evidence? Psychological science

*Correspondence: Alena Skalon, Swinburne University of Technology, Hawthorn, Melbourne, 3122 Australia. Email: askalon@swin.edu.au 
can provide some insight into the best ways in which to collect and handle identification evidence, as well as ways of presenting identification evidence to the jury that ensure the defendant's right to a fair trial.

\section{The facts of the case}

In November 2000, an 18-year-old female (referred to as GH) was walking in St Kilda when a Mini Minor car approached her and the driver suggested paying money in exchange for sex. GH agreed and got into the car. Shortly after they drove away, the driver punched GH in the face, drove down a narrow alley, blocked the passenger door and raped $\mathrm{GH}$, who eventually escaped from her attacker. GH testified that she decided not to report the crime to the police because she thought that they would not believe her. She did, however, report the incident to a health service for those involved in street-based sex work, as well as placing a description of her attacker on a noticeboard. According to her description, the man had 'short, blonde spikey hair' and 'ranga arms', and was 'evil eyed during the attack' (Bayley V The Queen, 2016, at [26]).

Twelve years after the attack, GH saw a photo of Adrian Bayley on Facebook when she was scrolling through a missing persons page. At this time she knew that Bayley had been arrested on 27 September for the rape and murder of Gillian Meagher (Bayley v The Queen, 2016). She called Crime Stoppers to report that she recognised him as the man who had raped her in 2000. The photo from which GH identified Bayley was taken 11 years after her rape. On 29 October 2012, she made a statement to a member of the homicide squad of the Victoria Police. On 1 February 2013, she was informed that Adrian Bayley had been charged with multiple offences against her, and 10 days later she was invited to the police station to view a photoboard of 12 men. GH admitted that between the initial Facebook identification and the photoboard identification she saw Bayley's photo in the media on multiple occasions in relation to Gillian Meagher's case. When GH identified the photo of Bayley from the photoboard, she said: 'It definitely looks like No. 4' (Bayley v The Queen, 2016, at [41]). By the time of this photoboard identification, $\mathrm{GH}$ had seen photos of Bayley multiple times, and she knew that he had been charged with the rape and murder of Gillian Meagher, as well as multiple charges against herself, including false imprisonment, assault and rape.

On 14 July 2015, Adrian Bayley was convicted by the County Court of Victoria of the offences against GH. In the original trial, the defence counsel sought to exclude the identification evidence on the basis of section 137 of the Evidence Act, 2008 (Vic): 'evidence should not be admitted if its probative value is outweighed by the danger of unfair prejudice to the defendant'. The judge refused to exclude the evidence, ruling that the probative value of the Facebook identification was not outweighed by unfair prejudice and that the photoboard identification had its own probative value. The County Court of Victoria's approach to section 137 aligns with Dupas V The Queen (2012) - the jury can accept evidence as credible without accepting it as reliable. In other words, the jury can hear the identification evidence but choose not to convict based on that evidence.

\section{The court of appeal judgement}

On appeal against the DPP v Bayley (2015) decision, the defence argued that the conviction was based on unsafe or unsatisfactory grounds; that is, that the evidence was too problematic and that the jury could not have reasonably rendered a guilty verdict based on such evidence. The Victorian Court of Appeal held that the identification evidence should not have been admitted in the first place and took a different approach to section 137, consistent with the High Court decision in IMM v The Queen (2016). It determined that while a trial 
judge should proceed on the assumption that the jury will accept the evidence and should not have regard to the credibility or reliability of the evidence, a trial judge should nevertheless exclude evidence if it is not merely weak but 'simply unconvincing' - if its probative value is scant.

In their decision, the Victorian Court of Appeal detailed six problems with the identification evidence:

1. The initial identification was made from a single photograph seen on Facebook.

2. The photograph from which the Facebook identification was made was taken 11 years after the rape.

3. The identification was made 12 years after the rape.

4. The circumstances of the identification were suggestive because $\mathrm{GH}$ was aware that Adrian Bayley was already under arrest for the rape and murder of Gillian Meagher.

5. The victim may have selected the photograph of Adrian Bayley from the formal police photoboard as a result of the displacement effect; in other words, GH's memory of the original perpetrator may have become contaminated after seeing Bayley's image on Facebook, which may in turn have influenced her identification during the photoboard.

6. The photoboard identification provided evidence of similarity - not identification-because when she selected Bayley, GH said: 'It [the perpetrator] definitely looks like number four [the photo of Adrian Bayley]' (Bayley v The Queen, 2016, at [58]).

After weighing the probative value of the identification evidence, the judge concluded that it should have been excluded at the initial trial. Because there was no other evidence, the court of appeal acquitted Bayley on all charges in GH's case.

\section{Issues with the identification evidence}

In its decision, the court cites several important factors that can undermine the reliability of identification evidence. In this article, answers to the issues outlined by the court of appeal are sought from the psychological literature. What does empirical research reveal about the influence of delay on identification accuracy? How reliable are identifications that are made from a single photograph? Does knowledge of the suspect's background influence the decision-making process? How does the displacement effect (seeing someone's face before the identification procedure) affect the reliability of an identification? In addition to briefly reviewing the psychology of eyewitness identification, the factors that may have influenced the jury's views as to this weak evidence and led them to render a guilty verdict in the initial trial are also discussed. It is important to emphasise that the aim of this article is to present the psychological research relevant to the case, rather than providing a legal analysis of the court's decision. Critically, GH's account of the assault and her decision to not initially report it are not in question, nor is any judgement being made about Bayley's involvement in the assault; rather, the aim is to present empirical evidence that explains why the identification evidence was not strong enough to uphold Bayley's conviction.

In an ideal world, memory would work like a recording device, copying events, storing them without error and reproducing them without modification. The reality is, however, that memory is a reconstructive process; memories are not preserved in an unchanged way. Memory is not a simple process. It includes three stages - encoding, storage and retrieval and at each stage information can be lost or contaminated (Foster, 2009). The issues with the identification evidence in this case are presented in line with this conceptualisation of memory. Differentiating the three stages of memory is important because it becomes possible to see how GH's memory may have been affected by outside factors - both before the 
police were contacted (e.g. the length of the delay and the circumstances of the Facebook identification) and after they became involved (e.g. how the photoboard identification procedure was conducted). This distinction between factors under and outside of the control of the criminal justice system is crucial, because the criminal justice system can only influence those factors that are under its direct control (Wells, 1978).

\section{Issues at the encoding stage}

The first stage, encoding, occurs when a person is first exposed to the material (Foster, 2009). Several factors can influence the quality of the memory at the encoding phase, including: how much attention the witness paid to the perpetrator's face; how long the witness saw the perpetrator (i.e. exposure duration); the quality of the witnessing conditions (such as lighting and distance); and the amount of stress experienced by the witness. Twelve years after the attack, it is difficult to reconstruct the quality of the witnessing conditions (e.g. the lighting, the exposure duration, etc.). What is certain, however, is that experiencing a violent sexual attack is undoubtedly an extremely stressful experience. During the attack, GH testified that she was 'pleading [for her] life' and 'was horrified and in agony' (Bayley v The Queen, 2016, at [30]).

\section{Stress}

Although people are unlikely to forget that a stressful event occurred, there are questions of practical importance relating to such events. How accurate are people's memories of the central details of a stressful event? Do people memorise the face of a perpetrator who is seen only once? In response to these questions, the research indicates that memories of highly stressful events are generally poor. A metaanalysis of 27 tests of eyewitnesses' identification performance indicates that stress levels are negatively correlated to identification accuracy (Deffenbacher, Bornstein, Penrod, \&
McGorty, 2004). Eyewitnesses who experience high levels of stress make more false identifications compared to low-stress circumstances. Although the evidence that stress impairs identification accuracy is robust, these results are based on experiments conducted in a laboratory under controlled conditions; one could argue that these laboratory results may not be indicative of the workings of memory in real-life situations.

One of the most realistic studies to date with unequivocally stressful conditions supports these laboratory findings. A total of 500 military personnel were interrogated during a survival-training programme designed to imitate the prisoner-of-war experience. All participants were interrogated under high- and low-stress conditions. In the high-stress condition, an interrogator physically confronted the participants; in the low-stress condition, another person interrogated the participants without physical confrontation. The interrogations lasted a total of 40 minutes each, with 4 hours between them. When the interrogation did not involve physical confrontation (i.e. the low-stress condition), $76 \%$ of participants correctly identified the interrogator from a simultaneous photoboard; in contrast, only $34 \%$ made an accurate identification when the interrogation was highly stressful. Similarly, $68 \%$ of participants in the high-stress condition made a false positive identification, compared to only $12 \%$ in the low-stress condition (Morgan et al., 2004). Similar results were obtained in another study that tested the accuracy of eyewitness identifications under stress. Valentine and Mesout (2009) recorded participants' heart rates and levels of anxiety during their visit to the London Dungeon. During the visit, the participants encountered a 'scary person' who they were later asked to describe and identify from a nine-person simultaneous target-present photoboard. Out of all the participants who experienced high levels of anxiety, only $17 \%$ correctly identified the 'scary person', compared to $75 \%$ of those with lower anxiety scores achieving a correct identification. 
Memories of highly stressful events are also more prone to incorporating false information. When participants in the survivaltraining course were presented with the photo of another person between the time of the interrogation and the presentation of the photoboard, $91 \%$ subsequently mistakenly identified that innocent person as their interrogator, even though the actual interrogator was not present on the photoboard (Morgan, Southwick, Steffian, Hazlett, \& Loftus, 2013).

\section{Issues at the storage stage}

The storage stage is the period between the initial exposure and later recollections of that information. Events that take place between the occurrence of a crime and the identification procedure (during the storage stage) can also influence an eyewitness's memory, because memory - even once encoded - is still susceptible to extraneous influences. Memories can fade if there is a long delay between the crime and the identification, and they also can be replaced or altered if an eyewitness discusses the event with other witnesses or police officers, or reads media reports.

\section{Delay}

GH identified Adrian Bayley 12 years after she was attacked. Common sense suggests that long delays may decrease identification accuracy - but what does the research show? Studies examining people's memory of onceseen faces after a delay can illuminate this matter. Most eyewitness studies investigating delay vary the time between exposure to the perpetrator and the identification attempt (usually from a photoboard) from one day to one week. A meta-analysis of 53 studies found that long delays reduce people's ability to identify once-seen faces (Deffenbacher, Bornstein, McGorty, \& Penrod, 2008). Shepherd, Ellis, and Davies (1982) reported the longest delay tested to date: 11 months. After a one-week delay, $65 \%$ correctly identified the perpetrator; in contrast, after an 11-month delay, only 10\% made an accurate identification.

The majority of these studies, however, focus on identifications made from photoboards, a procedure that differs from the conditions of GH's Facebook identification from a single photo. Research has demonstrated that the accuracy of making an identification from a single photo (i.e. a show-up) decreases within 24 hours (Dysart \& Lindsay, 2007). Although no research has examined the effects of a 12-year delay on a person's ability to recognise a perpetrator from Facebook, there is little reason to suspect that an identification made under these conditions would produce higher accuracy rates, given that memory consistently degrades over time. One could reasonably conclude that -12 years after the crime - GH's memory of the perpetrator would certainly be less reliable than it was immediately after the offence was committed.

\section{The influence of expectations}

When GH identified Bayley from Facebook, she was already aware of Gillian Meagher's death and knew that Bayley had been arrested for her rape and murder (Bayley v The Queen, 2016). Knowledge of a suspect's background can influence the expectations held by the witness and skew the decision-making process, increasing the probability of a false identification. Confirmation bias refers to the tendency to seek information that confirms one's expectations and beliefs while disregarding all other information (Plous, 1993). This bias occurs automatically, emerging regardless of a person's wishes or attempts to be impartial (Findley \& Scott, 2006; Kunda, 1990; Nickerson, 1998). This bias can be observed in a variety of tasks, but for the sake of brevity the ones that are most relevant to the forensic context are focused on herein.

When making identification decisions, eyewitnesses may be influenced by various factors, rather than basing their decisions solely on simple recognition. Factors such as beliefs about the case or hints given by the 
police officer during the identification procedure can skew an eyewitness's decision process. In a field simulation study examining eyewitness identifications from show-ups, the false identification rate was higher when eyewitnesses believed that they had witnessed an actual crime (40\%) compared to the laboratory conditions (13\%; Eisen, Smith, Olaguez, \& Skerritt-Perta, 2017). This result highlights the influence that emotions and expectations can have on decision-making.

In one study, the participants were exposed to a crime video and asked to make an identification from a photoboard that did not contain the perpetrator from the video. After making their identification decision, some participants were told that another photoboard member (not the one they had originally chosen) had confessed. The majority of the participants $(61 \%)$ changed their decision and instead identified the alleged confessor. Moreover, half of the participants who did not initially make an identification abandoned their original correct rejection to choose the alleged confessor (Hasel \& Kassin, 2009). This finding highlights the lack of independence of evidence and illustrates that eyewitnesses may be willing to identify a person even if they do not recognise him or her. This situation is dangerous because eyewitnesses may become invested in a choice that can replace their original memory altogether (see the section on the displacement effect).

Expectations can also influence eyewitnesses' behaviour in more subtle situations. For example, when eyewitnesses receive pre-identification instructions suggesting that the perpetrator is in the photoboard, they are more willing to choose someone compared to when they are warned that the perpetrator may or may not be present (for a meta-analysis of 18 studies, see Steblay, 1997; for a review, see Steblay, 2013). This willingness to choose - along with the associated consequences - is exacerbated when the photoboard does not contain the perpetrator. Furthermore, the photoboard administrator's expectations can also affect eyewitnesses' choices; when the administrator knows the suspect's identity, eyewitnesses are more than twice as likely to choose the suspect than any other photoboard member, regardless of the actual guilt of the suspect (Austin, Zimmerman, Rhead, \& Kovera, 2013; Canter, Hammond, \& Youngs, 2013), and they are more confident in their decision (Charman \& Quiroz, 2016). In a broader context, the influence of expectations on decision-making has also been studied in forensic science (for a review, see National Research Council, 2009). For example, if a forensic expert is aware that the suspect has confessed, the probability of finding a match between a sample found at the crime scene and a sample from the suspect increases. This effect has been observed in a handwriting comparison task (Kukucka \& Kassin, 2012), a fingerprint comparison (Dror, Peron, Hind, \& Charlton, 2005) and even DNA testing (Dror \& Hampikian, 2011).

In the present case, the details of the Facebook identification are unknown. It is unclear whether GH was scrolling down the page in order to identify her attacker or looking at the page for the details of Gillian Meagher's case or for some other purpose. What is certain, however, is that at the moment when GH first saw Bayley's photo, she was already aware of Bayley's involvement in Gillian Meagher's case. Thus, this knowledge may have influenced her expectations of Bayley and predisposed her to identify him as the person who raped her.

\section{Issues at the retrieval stage}

Retrieval is the process of actively searching for information. Every time a person tries to remember something, he or she is actually rebuilding or reconstructing that memory. It is during this reconstruction that errors can occur because information from other sources can be incorporated into the memory. Some of the factors that can affect accuracy at this stage are the way in which the identification 
procedure is conducted and the instructions that the officer gives to the witness prior to conducting a photoboard. These factors can affect the accuracy of future retrievals, as well as influencing the witness's confidence in that memory. In the present case, these factors include: the initial Facebook identification was made from a single photograph, which could have influenced the eyewitness's willingness to identify the person shown in the photo as the perpetrator; the memory for the perpetrator could have been displaced by Adrian Bayley's face; the photo was taken 11 years after the attack; and the appearance of the perpetrator might have changed.

\section{Single photograph identification}

GH initially identified Bayley from a single photograph on Facebook, which is similar to a show-up procedure. In a show-up, the police present the eyewitness with a single suspect or a photo of the suspect and ask the eyewitness to decide whether or not this person is the perpetrator (Dysart \& Lindsay, 2007). Why is a show-up problematic? First, it immediately reveals to the eyewitness the identity of the suspect, therefore influencing the eyewitness's expectations that the suspect is also likely to be the perpetrator (Dysart \& Lindsay, 2007). Second, when presented with the show-up, the eyewitness has only two options: identify the person or reject the photo. Thus, a show-up produces more identification errors compared to a photoboard (Gronlund et al., 2012). Moreover, performance on immediate show-ups is still worse than on delayed photoboards (Wetmore et al., 2016). Show-ups are particularly dangerous for innocent suspects, with eyewitnesses making more false identifications from show-ups compared to photoboards (Steblay, Dysart, Fulero, \& Lindsay, 2003). This risk increases with repeated show-ups (Smith et al., 2014).

In contrast, with a photoboard the eyewitness is shown the photos of a suspect and several foils (people who are known to be innocent), and is unaware of which person is the actual suspect. The addition of foils serves two important functions. First, it reduces the suggestiveness of the procedure because the eyewitness does not know which person is the police's suspect. Second, if the eyewitness chooses a foil, it demonstrates his or her willingness to choose from the photoboard even in the absence of strong recognition (Gronlund et al., 2012). In Bayley's case, however, the photoboard did not serve any of these functions because GH was aware of the identity of the suspect due to previously identifying him on Facebook.

\section{Displacement effect}

The court of appeal argued that a displacement effect could have taken place in that GH's initial memory of the perpetrator may have been displaced by the image of Adrian Bayley. The displacement effect was originally described in Alexander v The Queen (1981):

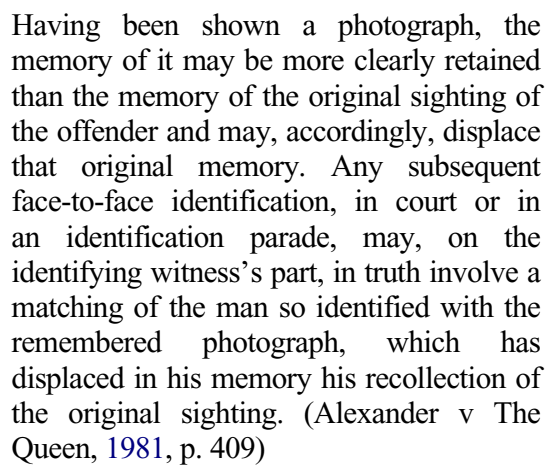

Although common in legal rulings, the term 'displacement effect' is not used in the psychological literature. Instead, psychologists would categorise the 'displacement effect' as the mugshot exposure effect. A mugshot exposure (i.e. viewing a photograph of a person prior to the identification procedure) decreases eyewitness identification accuracy (for a meta-analysis of the mugshot exposure effect, see Deffenbacher, Bornstein, \& Penrod, 2006). However, the term that best describes a situation wherein an eyewitness makes repeated identification decisions is the 
mugshot commitment effect. Once an eyewitness has identified someone, she or he is more likely to choose that same person again, even if that person is not the actual perpetrator. The eyewitness chooses the person again because she or he is committed to the initial identification decision (Dysart, Lindsay, Hammond, \& Dupuis, 2001). Although the consequences of the mugshot exposure effect and the mugshot commitment effect are similar (i.e. a person has been selected as the perpetrator), the mechanisms driving the eyewitness's decision-making process are different. In the case of mugshot exposure, the memory of one face replaces the memory of the perpetrator's face. In the case of commitment, however, the eyewitness is making the erroneous decision because he or she has previously identified that same person.

The commitment effect demonstrates that repeated identification decisions are not independent; an earlier decision can influence subsequent ones. This means that a second identification procedure cannot be used to confirm the eyewitness's identification from a previous procedure, as any correspondence between the decisions made during the two procedures may simply be the result of the commitment effect, and should not be interpreted as evidence of the eyewitness's accuracy (Lawson \& Dysart, 2015). In the Bayley case, GH made an initial identification decision before the formal photoboard, potentially resulting in the commitment effect.

\section{The photo was taken 11 years after the attack}

The court of appeal notes that the age of Adrian Bayley's photo at the time of the Facebook identification is one of the factors that diminishes the probative value of the evidence. This is an important consideration because a change in appearance (e.g. disguise, ageing) can affect identification accuracy (Laughery, Alexander, \& Lane, 1971; Mansour et al., 2012; Wells \& Hryciw, 1984). As one might expect, similarity between the perpetrator's appearance at the time of exposure and the time of identification increases the probability of making a correct identification (Molinaro, Arndorfer, \& Charman, 2013). If the perpetrator's facial hair or hairstyle changes between exposure and identification, this can impair identification accuracy (Patterson, 1978; Patterson \& Baddeley, 1977; Pozzulo \& Marciniak, 2007). One can argue, however, that Adrian Bayley's appearance did not significantly change between 2000 and 2011 (see Figure 1); thus, this factor may have had little influence on GH's decision to identify him.

\section{Evidence of similarity}

When GH identified Adrian Bayley from the photoboard, she said: 'It [the perpetrator] definitely looks like number four [the photo of Adrian Bayley]' (Bayley v The Queen, 2016, at [41]). The court of appeal used this statement to influence their interpretation of the weight of this evidence, deeming GH's selection to be evidence of similarity rather than evidence of a positive identification. The Australian Law Reform Commission Report (2006) describes evidence of identification as follows: 'Where a witness claims to recognise the defendant as the person seen on the relevant occasion' (section 13.11). On the other hand, evidence of similarity (or evidence of resemblance) is described as follows: 'Evidence that a person shares certain features or attributes in common with the accused or that he or she looks like the accused' (section 13.11). This raises the question of whether or not the choice of words that eyewitnesses use when making an identification is indicative of the weight of the evidence. To date, to the authors' knowledge no eyewitness studies have directly investigated whether or not the words that eyewitnesses use when making an identification can be indicative of one of two types of evidence: identification vs similarity evidence. Nonetheless, a relevant line of research to investigate lies in the 


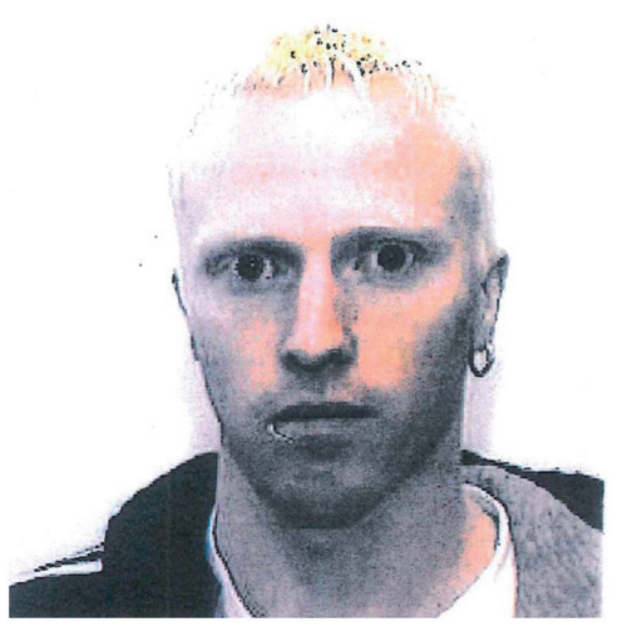

Figure 1. Adrian Bayley in 2000 (Source: County Court of Victoria)

decision-making processes that eyewitnesses use to make an identification, and how these processes relate to identification accuracy.

Wells (1984) suggests that when an eyewitness is presented with a photoboard, she or he can engage in one of two decision-making strategies: rendering relative or absolute judgements. The relative judgement strategy describes a process through which the eyewitness compares several photoboard members with each other, trying to find the closest match to her or his memory among those present. An eyewitness who uses relative judgement chooses the photoboard member who looks most like the perpetrator among the other members, provided that the member is a close enough match to the eyewitness's memory. This is a problematic strategy if the photoboard does not, in fact, contain the actual perpetrator. Thus, this puts an innocent suspect at risk if he happens to look more similar to the perpetrator than the other photoboard members (Wells, 1984, 1993). An absolute judgement, on the other hand, refers to a process through which the eyewitness identifies the photoboard member only when this member is a good match to the eyewitness's memory; thus, there are no between-member comparisons. Wells (1984) argues that an absolute judgement reduces the risk of false identification because the eyewitness makes a selection only when the suspect is a good match to her or his memory of the perpetrator, not when the suspect is simply the best match among the presented alternatives.

Other researchers conceptualise the eyewitness identification decision-making process as being either automatic or deliberative. Dunning and Stern (1994) measured the underlying decision-making processes by asking eyewitnesses to explain how they had reached their decisions. The endorsement of statements that reflect making comparisons between line-up members or engaging in a process of elimination suggests a more deliberative strategy rather than automatic recognition. The accurate eyewitnesses tended to report automatic recognition of the perpetrator (i.e. that the person 'stood out' to them), whereas the inaccurate eyewitnesses tended to describe engaging in a deliberative process of eliminating the other options until they had found a satisfactory match (Dunning \& Stern, 1994).

This distinction between automatic recognition and a process of elimination resembles the court's distinction between evidence of identification and evidence of similarity, respectively. However, to date there is no empirical evidence to show a distinction between evidence of similarity and evidence of identification. In the present case, when GH chose the photo of Adrian Bayley, she said: 'it definitely looks like ...' but did not indicate that she had based her decision on a comparison amongst photoboard members (e.g. 'it looks most like ...'). As such, it is difficult to evaluate the court of appeal's reasoning in light of the current scientific evidence. More research is necessary to support the court's willingness to give more weight to evidence of identification than evidence of similarity by exploring how the two conceptualisations relate to identification accuracy. 


\section{Summary and additional considerations}

As previously mentioned, it is important to differentiate between factors that are not under the control of the criminal justice system (e.g. the length of the delay between exposure and identification, and the circumstances of the Facebook identification) and those that can be controlled (e.g. how the photoboard identification procedure is conducted). Nonetheless, evidence obtained under suggestive circumstances can still influence jurors' judgements and their willingness to convict the defendant.

The present case illustrates that memory is fragile. At each of the three stages of memory multiple factors can undermine its accuracy and, consequently, the reliability of identification evidence. The authors of the current article agree with the court's ruling that GH's photoboard identification should not have been admitted as evidence against Bayley because the circumstances under which the identification was obtained were overly suggestive. Now, however, the focus of this article turns to another matter - namely, the jury's decision to convict Bayley at the initial trial despite the weak evidence against him.

\section{Why did the jury render a guilty verdict?}

An impartial jury ensures that the defendant's right to a fair trial is met. The notion of the jury's impartiality - basing their verdict entirely on the evidence presented at trial, rather than on beliefs or information obtained outside the courtroom - is one of the basic assumptions of the Australian criminal justice system. However, an important question remains: can jurors ignore extralegal information and base their decisions only on the evidence presented at trial? The jury convicted Bayley despite multiple weaknesses in the identification evidence and the defence's attempt to educate the jurors by asking an expert psychologist Associate Professor Richard Kemp - to testify about the problems with it.
The court of appeal disagreed with the jury's verdict and argued that the evidence was too weak to support a guilty verdict:
Having made our own independent assessment of the evidence as a whole, we are firmly of the view that a properly instructed jury, applying themselves appropriately to their task, must have had a reasonable doubt as to the applicant's guilt. GH's identification evidence was so weak that no other conclusion was reasonably open. (Bayley $\mathrm{v}$ The Queen, 2016, at [99])

Eyewitness evidence is extremely persuasive to jurors (Boyce, Beaudry, \& Lindsay, 2007). The mere presence of such evidence - regardless of its reliability - can drastically increase guilt ratings (Loftus, 1974). People attribute disproportionate weight to eyewitness evidence partially because they overestimate the accuracy of eyewitness memory. For example, Brigham and Bothwell (1983) presented descriptions of previously conducted studies and asked participants to predict the accuracy of those eyewitnesses. The vast majority of the participants overestimated the eyewitnesses' accuracy rates, illustrating an 'overbelief' in eyewitnesses and a general lack of knowledge of the factors that can influence eyewitness accuracy. Even when the jurors are aware of the suggestiveness of an identification procedure, they can still decide to believe eyewitness evidence (e.g. Devenport, Stinson, Cutler, \& Kravitz, 2002). Thus, although jurors may be able to distinguish between fair and suggestive procedures, they will not necessarily use this information when rendering a verdict. The persuasiveness of eyewitness evidence, coupled with a lack of knowledge of the factors that can influence eyewitness evidence and a disregard of the dangers of suggestive procedures, increases the risk of juries basing their decisions on unreliable evidence.

Furthermore, by the time of GH's case, Adrian Bayley had already been convicted of the rape and murder of Gillian Meagher, whose tragic death had attracted significant media 
attention. Thousands of people participated in a march in memory of Gillian on 30 September 2013 (Zielinski, 2013). Even though GH's case was heard in 2014, it is highly probable that the jurors still remembered the circumstances of Gillian Meagher's death, and that Adrian Bayley had pleaded guilty to her murder. This knowledge might have influenced the jurors' expectations and skewed their perception of the defendant in favour of the prosecution before the trial had even begun.

Pretrial publicity can expose jurors to information about a case that may not be true or may not be admissible in court, such as non-existent evidence or the defendant's history of prior offences. This pretrial information may irreversibly bias jurors' perceptions of the case. Subsequent information presented in the court case itself may be perceived through the lens of pretrial publicity. Research into the effects of pretrial publicity has found that it increases jurors' willingness to convict the defendant (for a meta-analysis, see Steblay, Besirevic, Fulero, \& Jimenez-Lorente, 1999), decreases the perceived credibility of the defendant and elicits a negative emotional response from jurors (Ruva, Guenther, \& Yarbrough, 2011). This effect is even stronger in cases involving sexual assault and murder compared to other types of cases (Steblay et al., 1999). The influence of pretrial publicity is so strong that not even traditional legal safeguards such as jury selection and judicial instructions have been able to overcome its biasing effects (Kramer, Kerr, \& Carroll, 1990; Lieberman \& Arndt, 2000). Moreover, the deliberation process - which is believed to serve as a safeguard against any individually held prejudices - actually does the opposite, by increasing the damaging effects of pretrial publicity and leading to more guilty verdicts than reported in predeliberation voting (Kramer et al., 1990). Furthermore, social media (e.g. Facebook) and the Internet can also compromise the independence of jury decision-making, as jurors can search for information about the case despite being instructed not to do so.

The identification made by GH was persuasive to the jury because she testified about her first-hand experience, and jurors can be insensitive to factors that undermine the reliability of an identification. Moreover, given the widespread media attention received by this case, it is possible that the jury still remembered who Adrian Bayley was and that this knowledge affected their decision-making processes. Examples such as this illustrate the need for the revision of the criminal justice system's perceptions of jurors as purely rational decision-makers, and the need to focus on ways to improve the accuracy of jurors' evaluations of eyewitness evidence.

\section{Discussion}

This article highlights several issues regarding the probative value of the identification evidence in Adrian Bayley's trial. For the most part, psychological research supports the issues identified by the court of appeal (i.e. delay, change in appearance, single photograph identification and the influence of expectations). However, two issues require additional scrutiny. First, the court raised concerns about the possibility of GH's memory of the perpetrator being displaced by the image of Bayley's photo during the Facebook identification. In the legal literature this is known as the displacement effect. However, in the psychological literature a similar phenomenon is called the mugshot exposure effect. The use of these different terms that appear to be describing the same effect may contribute to confusion and miscommunication between legal practitioners and psychological scholars. Moreover, in the case of GH's photoboard identification, the mugshot commitment effect offers the best explanation: GH did not simply see Adrian Bayley - she identified him from the Facebook photograph, a situation that is different from the traditional mugshot exposure effect. Second, drawing a distinction between evidence of identification and 
evidence of similarity based on the choice of words that the eyewitness uses when making an identification lacks empirical support. Although eyewitnesses' self-reported decision-making strategies may correlate with their identification accuracy, there is conflicting research on the utility of this correlation (e.g. Ross, Benton, McDonnell, Metzger, \& Silver, 2007), and it is not yet clear how these decision-making processes correspond to any distinction between the two types of evidence.

A separate issue is the jury's decision to convict Bayley at the initial trial based on the weak identification evidence alone. Laypeople may not possess appropriate knowledge about the factors that can affect eyewitness accuracy, and are often convinced by identification evidence regardless of the quality of the witnessing and identification conditions. The media coverage surrounding Bayley may have also played a role in this case. Jurors may find it difficult to make decisions independent of information they have seen or heard outside of the courtroom; even when instructed not to do so, they still have a tendency to rely on information heard elsewhere when deciding the case. Future research must find more effective ways of educating jurors and/or increasing the role of judges as gatekeepers of this type of evidence.

Bayley v The Queen (2016) adds to a number of other cases in which a Facebook identification was an issue. Identifications made on Facebook provide new challenges to the criminal justice system as these judgements are made outside the police station, without the benefit of any of the traditional safeguards used to ensure the fairness of the procedure. Moreover, an initial Facebook identification may contaminate the eyewitness's memory of the perpetrator and significantly increase the risk of the commitment effect taking place during subsequent formal identification procedures. How are these emerging Facebook identifications currently dealt with in Australia? McGorrery (2015) provides an overview of five recent cases that discuss such identifications. Only one case rendered the Facebook identification inadmissible (Strauss V The Police, 2013); in the four other cases, the Facebook identification evidence was admitted, even though these identifications were made under highly suggestive circumstances and in the absence of any safeguards.

These leading cases are likely to influence how the police and the courts will approach Facebook identifications in future cases. In his recommendations, McGorrery (2015) underlines the importance of collecting initial statements from eyewitnesses at the crime scene and warning them not to use Facebook. Obtaining an uncontaminated confidence statement is of the utmost importance, as the eyewitness's confidence at the time of the identification can be indicative of her or his accuracy (Brewer \& Wells, 2006; Wixted \& Wells, 2017). It is unclear, however, whether or not the confidence-accuracy relationship has similar utility in cases of Facebook identification. McGorrery also argues that the formal identification procedure should be conducted even if an eyewitness has already identified the suspect on Facebook. He notes that even though there is a high risk of the displacement effect occurring, the formal procedure can highlight the unreliability of an eyewitness if he or she fails to identify the suspect from the photoboard (Strauss $\mathrm{v}$ The Police, 2013). However, it is the opinion of the current authors that any subsequent procedure should not be admitted in court, because it may be the result of the commitment effect rather than an indication of a strong memory of the suspect as the perpetrator (see Steblay \& Dysart, 2016).

\section{Conclusion}

This article demonstrates that lawyers and psychologists may reach the same conclusions but use different reasoning and evidence to inform their decisions. Judges base their decisions on the events observed in the case before them and use legal precedents; psychologists, 
on the other hand, rely on findings from experimental studies that are generally accepted in their field. Some of the court of appeal's case observations correspond to the findings of psychological studies, but others do not. This case highlights some of the issues that are yet to be addressed by psychological science. The ways in which Facebook identifications differ from traditional forms of identification are unclear, along with the best way to communicate with eyewitnesses in such cases. The difference between evidence of similarity and evidence of identification is also a gap that psychologists need to fill. Furthermore, it is important to underline the need for continued interaction between psychological researchers and legal practitioners; only through establishing ongoing communication can the consistency and effectiveness of legal decisions and the applicability and relevance of psychological research be ensured.

\section{Acknowledgements}

We would like to thank Professor James Ogloff for his comments on an earlier version of this article and for his guidance and expertise. We would also like to thank Dr Mehera San Roque for her advice. We are grateful to Professor Mirko Bagaric for his suggestions, and to $\mathrm{Dr}$ Michelle Noon and $\mathrm{Mr}$ Jamie Smith-Morvell for their thorough reviews and insightful suggestions.

\section{Funding}

This work was supported by the Swinburne Postgraduate Research Award [grant number $\mathrm{xxx}$ ]

\section{Ethical standards}

\section{Declaration of conflicts of interest}

Alena Skalon has declared no conflicts of interest.

Jennifer L. Beaudry has declared no conflicts of interest.

\section{Ethical approval}

This article does not contain any studies with human participants or animals performed by any of the authors.

\section{References}

Alexander v The Queen. (1981). 145 CLR 395.

Austin, J. L., Zimmerman, D. M., Rhead, L., \& Kovera, M. B. (2013). Double-blind lineup administration. In B. L. Cutler (Ed.), Reform of eyewitness identification procedures (pp. 139-160). Washington, DC: The American Psychological Association.

Australian Law Reform Commission Report (ALRC). (2006, February, 8). ALRC Report 102. Retrieved from https://www.alrc.gov.au/ publications/report-102

Bayley v The Queen. (2016). VSCA 160

Boyce, M. A., Beaudry, J. L., \& Lindsay, R. C. L. (2007). Belief of eyewitness identification evidence. In R. Lindsay, D. Ross, D. Read, \& M. Toglia (Eds.), Handbook of Eyewitness Psychology: Memory for People (pp. 501-525). Mahwah, NJ: Lawrence Erlbaum and Associates.

Brewer, N., \& Wells, G. L. (2006). The confidence-accuracy relationship in eyewitness identification: effects of lineup instructions, foil similarity, and target-absent base rates. Journal of Experimental Psychology: Applied, 12, 11.

Brigham, J. C. \& Bothwell, R. K. (1983). The ability of prospective jurors to estimate the accuracy of eyewitness identifications. Law and Human Behavior, 7, 19-30.

Canter, D., Hammond, L., \& Youngs, D. (2013). Cognitive bias in line-up identifications: the impact of administrator knowledge. Science \& Justice 53, 83-88.

Charman, S. D., \& Quiroz, V. (2016). Blind sequential lineup administration reduces both false identifications and confidence in those false identifications. Law and Human Behavior, 40(5), 477-487. doi: 10.1037/ $1 \mathrm{hb} 0000197$

Deffenbacher, K. A., Bornstein, B. H., McGorty, E. K., \& Penrod, S. D. (2008). Forgetting the once-seen face: estimating the strength of an eyewitness's memory representation. Journal of Experimental Psychology: Applied, 14(2), 139-150. doi: 10.1037/ 1076-898X.14.2.139

Deffenbacher, K. A., Bornstein, B. H., \& Penrod, S. D. (2006). Mugshot exposure effects: retroactive interference, source 
confusion, and unconscious transference. Law \& Human Behavior, 30, 287-307. doi: 10.1007/s10979-006-9008-1

Deffenbacher, K. A., Bornstein, B. H., Penrod, S. D., \& McGorty, E. K. (2004). A metaanalytic review of the effects of high stress on eyewitness memory. Law and Human Behavior, 28(6), 83-706. doi: 10.1007/ s10979-004-0565-X

Devenport, J. L., Stinson, V., Cutler, B. L., \& Kravitz, D. A. (2002). How effective are the crossexamination and expert testimony safeguards? Jurors' perceptions of the suggestiveness and fairness of biased lineup procedures. Journal of Applied Psychology, 87(6), 1042-1054.

DPP v Bayley. (2015). VSCA 698, conviction trial 1

Dror, I. E., \& Hampikian, G. (2011). Subjectivity and bias in forensic DNA mixture interpretation. Science \& Justice, 51, 204-208. Retrieved from doi: 10.1016/ j.scijus.2011.08.004

Dror, I. E., Peron, A. E., Hind, S. -L., \& Charlton, D. (2005). When emotions get the better of us: The effect of contextual top-down processing on matching fingerprints. Applied Cognitive Psychology, 19, 799-809. Retrieved from doi: 10.1002/acp.1130

Dunning, D., \& Stern, L. B. (1994). Distinguishing accurate from inaccurate eyewitness identifications via inquiries about decision processes. Journal of Personality and Social Psychology, 67(5), 687.

Dupas v The Queen. (2012). 40 VR 182.

Dysart, J. E., \& Lindsay, R. C. L. (2007). Show-up identifications: Suggestive technique or reliable method? In R. C. L. Lindsay, D. F. Ross, M. P. Toglia, \& D. Read (Eds.), The handbook of eyewitness psychology, Volume 2: Memory for people (pp. 137-153). Mahwah, NJ: Lawrence Erlbaum Associates.

Dysart, J. E., Lindsay, R. C. L., Hammond, R., \& Dupuis, P. (2001). Mug shot exposure prior to lineup identification: Interference, transference, and commitment effects. Journal of Applied Psychology, 86(6), 1280-1284. doi: 10.1037/0021-9010.86.6.1280

Eisen, M. L., Smith, A. M., Olaguez, A. P., \& Skerritt-Perta, A. S. (2017). An examination of showups conducted by law enforcement using a field-simulation paradigm. Psychology, Public Policy, and Law, 23(1), 1-22. Retrieved from doi: 10.1037/ law0000115
Evidence Act. (2008). Evidence Act 2008 (Vic). Retrieved from http://www.austlii.edu.au/au/ legis/vic/consol_act/ea200880/

Findley, K. A., \& Scott, M. S. (2006). The multiple dimensions of tunnel vision in criminal cases. Wisconsin Law Review, 2, 1023.

Foster, J. K. (2009). Memory: A very short introduction. Oxford: Oxford University Press.

Gronlund, S. D., Carlson, C. A., Neuschatz, J. S., Goodsell, C. A., Wetmore, S. A., Wooten, A., et al. (2012). Showups versus lineups: An evaluation using ROC analysis. Journal of Applied Research in Memory and Cognition, 1, 221-228.

Hasel, L. E., \& Kassin, S. M. (2009). On the presumption of evidentiary independence: Can confessions corrupt eyewitness identifications? Psychological Science, 20, 122-126. Retrieved from doi: $10.1111 / \mathrm{j} .1467-$ 9280.2008.02262.x

IMM v The Queen. (2016). 330 ALR 382

Kramer, G. P., Kerr, N. L., \& Carroll, J. S. (1990). Pretrial publicity, judicial remedies, and jury bias. Law and Human Behavior, 14, 409-438.

Kukucka, J., \& Kassin, S. M. (2012, April). Do confessions taint juror perceptions of handwriting evidence? Paper presented at the Annual Meeting of the American Psychology-Law Society San Juan, Puerto Rico, March 14-17.

Kunda, Z. (1990). The case for motivated reasoning. Psychological Bulletin, 108, 480-498. doi: 10.1037/0033-2909.108.3.480

Laughery, K. R., Alexander, J. F., \& Lane, A. B. (1971). Recognition of human faces: Effects of target exposure time, target position, pose position and type of photograph. Journal of Applied Psychology, 51, 477-483.

Lawson, V. Z., \& Dysart, J. E. (2015). Searching for suspects: Mugshot files and showups (street identifications). In $\mathrm{T}$. Valentine, \& J. Davis (Eds.), Forensic facial identification: Theory and practice of identification from eyewitnesses, composites and CCTV (pp. 71-92). Chichester: Wiley Blackwell. http://onlinelibrary.wiley.com/doi/ 10.1002/9781118469538.ch4/summary

Lieberman, J. D., \& Arndt, J. (2000). Understanding the limits of limiting instruction: Social psychological explanations for the failure of instructions to disregard pretrial publicity and other inadmissible evidence. Psychology, Public Policy, and Law, 6, 677-711. 
Loftus, E. F. (1974). Reconstructing memory: The incredible witness. Psychology Today, 8 , 116-119.

Mansour, J. K., Beaudry, J. L., Bertrand, M. I., Kalmet, N., Melsom, E. I., \& Lindsay, R. C. (2012). Impact of disguise on identification decisions and confidence with simultaneous and sequential lineups. Law and human behavior, 36(6), 513.

McGorrery, P. (2015). The limited impact of Facebook and the displacement effect on the admissibility of identification evidence. Criminal Law Journal, 39(4):208.

Molinaro, P. F., Arndorfer, A., \& Charman, S. D. (2013). Appearance-change instruction effects on eyewitness identification accuracy are not moderated by amount of appearance change. Law and Human Behavior, 37, 432-440. doi: 10.1037/lhb0000049

Morgan, C. A., III, Hazlett, G., Doran, A., Garrett, S., Hoyt, G., Thomas, P., et al. (2004). Accuracy of eyewitness memory for persons encountered during exposure to highly intense stress. International Journal of Law and Psychiatry, 27(3), 265-279.

Morgan, C. A., Southwick, S., Steffian, G., Hazlett, G. A., \& Loftus, E. F. (2013). Misinformation can influence memory for recently experienced, highly stressful events. International journal of law and psychiatry, 36(1), 11-17.

National Research Council. (2009). Strengthening forensic science in the United States: a path forward. Washington, DC: National Academies Press.

Nickerson, R. S. (1998). Confirmation bias: A ubiquitous phenomenon in many guises. Review of General Psychology, 2, 175-220. Retrieved from doi: 10.1037/ 1089-2680.2.2.175

Patterson, K. E. (1978). Person recognition: More than a pretty face. In M. M. Gruneberg, P. E. Morris, \& R. N. Sykes (Eds.), Practical Aspects of Memory (pp. 227-235). London: Academic Press.

Patterson, K. E., \& Baddeley, A. D. (1977). When face recognition fails. Journal of Experimental Psychology: Human Learning and Memory, 3, 406-417.

Plous, S. (1993). The psychology of judgment and decision making. New York: McGrawHill.

Pozzulo, J. D., \& Marciniak, S. (2007). Comparing identification procedures when the perpetrator has changed appearance. Psychology, Crime, and Law, 12, 429-438.
Ross, D. F., Benton, T. R., McDonnell, S., Metzger, R., \& Silver, C. (2007). When accurate and inaccurate eyewitnesses look the same: a limitation of the 'pop-out'effect and the 10-to 12-second rule. Applied Cognitive Psychology, 21, 677-690.

Ruva, C. L., Guenther, C. C., \& Yarbrough, A. (2011). Positive and negative pre-trial publicity: The roles of impression formation, emotion and predecisional distortion. Criminal Justice and Behavior, 38, 511-534. doi: 10.1177/0093854811400823

Shepherd, J. W., Ellis, H. D., \& Davies, G. M. (1982). Identification evidence: A psychological evaluation. Aberdeen: Aberdeen University Press.

Smith, A. M., Bertrand, M., Lindsay, R. C. L., Kalmet, N., Grossman, D., \& Provenzano, D. (2014). The impact of multiple show-ups on eyewitness decision-making and innocence risk. Journal of Experimental Psychology: Applied, 20, 247-259. Retrieved from doi: 10.1037/xap0000018

Steblay, N. (1997). Social influence in eyewitness recall: A meta-analytic review of lineup instruction effects. Law and Human Behavior, 21(3), 283-297. Retrieved from doi: 10.1023/A:1024890732059

Steblay, N. (2013). Lineup instructions. In B. L. Cutler (Ed.), Reform of eyewitness identification (pp. 65-86). Washington, DC: American Psychological Association.

Steblay, N., Besirevic, J., Fulero, S. M., \& Jimenez-Lorente, B. (1999). The effects of pretrial publicity on juror verdicts: A metaanalytic review. Law and Human Behavior, 23(2), 219.

Steblay, N., Dysart, J., Fulero, S., \& Lindsay, R. C. L. (2003). Eyewitness accuracy rates in police showup and lineup presentations: A meta-analytic comparison. Law and Human Behavior, 27, 523-540. doi: 10.1023/A: 1025438223608

Steblay, N. K., \& Dysart, J. E. (2016). Repeated eyewitness identification procedures with the same suspect. Journal of Applied Research in Memory and Cognition, 5, 284-289

Valentine, T., \& Mesout, J. (2009). Eyewitness identification under stress in the London Dungeon. Applied Cognitive Psychology, 23, 151-161.

Strauss V The Police. (2013). Strauss v. The Police. 115 SASR 90

w? $>$ Wells, G. L. (1978). Applied eyewitness-testimony research: System variables and estimator variables. Journal of Personality and Social Psychology, 36, 1546-1557. 
Wells, G. L. (1984). The psychology of lineup identifications. Journal of Applied Social Psychology, 14, 89-103.

Wells, G. L. (1993). What do we know about eyewitness identification? American Psychologist, 48, 553-571. doi: 10.1037/ 0003-066X.48.5.553

Wells, G. L., \& Hryciw, B. (1984). Memory for faces: Encoding and retrieval operations. Memory \& Cognition, 12, 338-344.

Wetmore, S. A., Neuschatz, J. S., Gronlund, S. D., Wooten, A., Goodsell, C. A., \& Carlson, C. A. (2016). Effect of retention interval on showup and lineup performance:
Corrigendum. Journal of Applied Research in Memory and Cognition, 5(1), 94. doi: 10.1016/j.jarmac.2015.11.001

Wixted, J. T., \& Wells, G. L. (2017). The relationship between eyewitness confidence and identification accuracy: A new synthesis. Psychological Science in the Public Interest, 18(1), 10-65.

Zielinski, C. (2013, September 30). Thousands march to remember Jill Meagher. The Age. Retrieved from http://www.theage.com.au/ victoria/thousands-march-to-remember-jillmeagher-20130929-2umj1.html 